\title{
УКРАЇНСЬКА ЛІТЕРАТУРНА МОВА ТА І. ФРАНКО: ПРОБЛЕМА КОДИФІКАЦЇ̈
}

\author{
Шмілик І. Д.
}

\section{ВСТУП}

Літературна мова - унормована мова суспільного спілкування, загальноприйнятна в писемній та усній практиці, основними ознаками якої $\epsilon$ «наддіалектний характер, стабільні літературні норми в граматиці, лексиці, вимові, функціонально-стильова розгалуженість» ${ }^{1}$.

У кінці XIX - на початку XX ст. українська літературна мова переживала надзвичайно складний етап свого розвитку, оскільки «суспільно-політичні умови, в яких перебував український народ, розділений між Російською та Австро-Угорською імперіями, спричинили існування двох варіантів літературної мови східноукраїнського та західноукраїнського, що характеризувалися відповідними регіональними нормами» ${ }^{2}$. Тобто «нова українська літературна мова (на народній основі) з кінця XVIII - початку XIX ст. розвивалася в основному під впливом двох літературно-мовних традицій: 1) східноукраїнської (наддніпрянської); 2) західноукраїнської (наддністрянської, або галицької), яка з 60-70-х років має щодалі більш виражену тенденцію наближатись до східноукраїнської ${ }^{3}$ У Галичині літературно-мовна традиція старокнижної мови XVIII ст. фактично не переривається в XIX ст., як це було наприкінці XVIII ст. - на початку XIX ст. у Східній Україні, де витворюється літературна мова на народній основі. Ця традиція старокнижної мови відчутна в Галичині протягом усього XIX ст. і навіть на початку XX ст. Відповідно, дослідження передумов виникнення та особливостей західноукраїнського варіанта літературної мови кінця XIX - початку $\mathrm{XX}$ ст. - це «неуникненне завдання, що не розв'язавши його годі дійти історично вірогідних висновків про роль того чи іншого просторовочасового континууму в формуванні узвичаєних, а згодом i

Єрмоленко С.Я. Літературна мова. Енциклопедія / ред. кол.: В.М. Русанівський, О.О. Тараненко (співголови). 2-ге вид., випр. і доп. Київ : «Українська енциклопедія» ім. М. Бажана. 2004. С. 318.

${ }^{2}$ Там само. С. 319.

3 Жилко Ф.Т. Мова Івана Франка (Лекція для студентів-заочників факультету мови і літератури). Київ-Львів : Радянська школа, 1949. С. 2. 
кодифікованих норм української літературної мови» ${ }^{4}$. Отже, мета нашого дослідження - прослідкувати особливості варіантів літературної мови, зокрема західноукраїнського, а також проаналізувати, яку роль відіграла мова поезій I. Франка в унормуванні української літературної мови. Постать Каменяра та його роль у становленні української літературної мови, особливості Франкової мови неодноразово були представлені і в розділах з історії української мови (В. Русанівський, І. Огієнко, В. Чапленко), і в окремих розвідках П. Коваліва， В. Лева， Ф. Жилка， В. Грещука， 3. Терлака， М. Лесюка, I. Ціхоцького тощо. Однак і нині залишається не до кінця висвітленою роль його поезій у становленні української літературної мови, оскільки до І. Франка в Галичині не було єдності в думках щодо шляхів іiі розвитку й нормування i, відповідно, письменник був змушений працювати в умовах, коли «поряд із літературною мовою на народній основі існувало «язичіє» 5 .

\section{1. Варіанти української літературної мови: передумови виникнення та особливості}

Варіантність української літературної мови кінця XIX - початку XX ст. - східного та західного, що було «насамперед наслідком державно-політичної роз'єднаності українських земель, відбувалося в умовах контактування 3 мовами вищого політичного та суспільного статусу (німецькою, російською), 3 мовами, на які українська інтелігенція культурно орієнтувалася (російською, німецькою, польською, церковнослов'янською), а також зі співтериторіальними мовами (польською, румунською, німецькою, угорською)» ${ }^{6}$. Варто зазначити, що на межі століть українці були поділені між трьома державами - Росію, Австрією та Угорщиною (з яких останні дві були об'єднані в Австро-Угорщину) -та підлягали трьом різним законодавствам. Як зазначає Ю. Шевельов, «приблизно 85\% українців, що жили на території, яка належала до Росії, перебували в найгіршому становищі; коло 13\% у Східній Галичині та Буковині, приєднаній до Австрії втішалися порівняно набагато кращими умовами; решта $2 \%$, на Закарпатті, жили в обставинах, ближчих до обставин на підросійській

${ }^{4}$ Ткач Л. Українська літературна мова на Буковині в кінці XIX - на початку $\mathrm{XX}$ с. Частина 2: Джерела і соціокультурні чинники розвитку. Чернівці : Книги-XXI, 2007. C. 12.

5 Гримашевич Г. Концепція взаємодії літературної мови та діалектів у мовознавчій спадщині Івана Франка. Волинь-Житомирщина. 2006. № 15. С. 209.

${ }^{6}$ Ткач Л. Українська літературна мова на Буковині в кінці XIX - на початку XX с. Частина 2: Джерела і соціокультурні чинники розвитку. Чернівці : Книги-XXI, 2007. C.14. 
Україні» ${ }^{7}$. Зазначмо, що на підросійській Україні українську мову було повністю усунено зі всіх сфер життя, зокрема, ії не використовували ані під час дискусій, ані при написанні творів; не користувалися в науці, так само як і не провадили нею навчання в школах, ані в початкових, ані в вищих ${ }^{8}$.

У 1876 р. був прийнятий так званий «Емський указ», яким заборонялося видавати книжки українською мовою, а саме переклади 3 інших мов, а також ввозити 3-за кордону українські книжки. Відповідно, український мовно-культурний рух після 1876 p. переноситься зі Східної України в Західну, а головним осередком стає Львів ${ }^{9}$. Мовно-літературна практика в Східній Галичині, за визначенням С. Гірняк, - «це варіант української літературної мови зі специфічними ознаками, зумовленими історичними, політичними, соціальними та мовними чинниками, який функціонував на українських землях краю упродовж XIX - першої половини XX ст.» ${ }^{10}$.

Зауважимо, що на початку XIX ст. в Європі під впливом ідеї просвітництва пробудився інтерес до народної творчості, а отже, і до мови. Ці ідеї в 30-ті роки дійшли й до Галичини. У центрі національнокультурного відродження була «Руська трійця» - М. Шашкевич, I. Вагилевич та Я. Головацький. Але ще у 20-ті роки став помітним «процес усвідомлення галицькою інтелігенцією єдності української мови наддніпрянської $з$ наддністрянською, необхідності іï вивчення та розбудови, впровадження в освіту й науку» ${ }^{11}$. Варто зазначити, що віденська влада не накладала заборон на розвиток української мови та української школи, однак й не була особливо зацікавленою в тому, щоби «рутенська» мова використовувалася 3 освітньою метою. На перешкоді розвитку української мови стояла і західноукраїнська клерикальна інтелігенція, яка відстоювала «вчений руський язик», тобто у своїй основі церковнослов'янську мову ${ }^{12}$. У середині та в другій половині XIX ст. у Галичині українці поділилися на чотири партії (руська, русько-польська, русько-австрійська й русько-

7 Шевельов Ю. Українська мова в першій половині двадцятого століття (1900-1941): Стан і статус. Чернівці : Рута, 1998. С.11.

${ }^{8}$ Там само. C.13.

9 Русанівський В. Історія української літературної мови. Київ : Артек, 2001. C. 227.

${ }^{10}$ Гірняк С.П. Роль соціолекту інтелігенції східної Галичини у формуванні норм української літературної мови (кінець XIX - перша половина XX ст.) : дис. ... докт. філол. наук : 10.02.01 «Українська мова». Дрогобицький державний педагогічний університет імені Івана Франка. Дрогобич, 2018. С. 50.

${ }_{11}$ Русанівський В. Історія української літературної мови. Київ : Артек, 2001. C. 224-225.

12 Там само. С. 225. 
московська), це зумовило відбиток і на творенні літературної мови, зокрема 31849 р. почалися суперечки щодо мови і правопису. Карпатські українці вважали, що літературною мовою не може бути жива народна мова, лише церковнослов'янська. Народилося велике число т.зв. «москвофілів», батьком яких став український історик Д. Зубрицький; до нього приєдналися проф. Я. Головацький, Гушалевич, А. Петрушевич. Відповідно, з 1851 р. у Галичині виникає нова літературна мова - «українсько-російське язичіє» ${ }^{13}$.

Згодом у Галичині та Буковині, що належали до Австрії, почала діяти порівняно ліберальна конституція 1867 р. На відміну від підросійської України, українська мова в Австрії не була заборонена в громадському житті. «Після періоду модного захоплення москвофільством вже у дев'яностих роках основна маса духовенства повертається до українства. Щодо богослужб, то їх завжди відправляли церковнослов'янською мовою 3 українською вимовою» ${ }^{14}$.

Національне відродження в Галичині супроводжувалося заснуванням великої кількості шкіл із народною мовою викладання, багато уваги починало приділятися виробленню українського алфавіту й правопису. I хоча Емський указ «надовго поклав кінець і спробам виробити оригінальне українське письмо і намаганням впорядкувати українську граматику», однак розвиток граматичної думки i словникарства в Східній Україні позитивно вплинув на пробудження наукової уваги до української мови в Галичині й у Закарпатській Україні ${ }^{15}$. Особливість мовної ситуації в Галичині полягала в тому, що освічені українці хоч і розмовляли між собою по-українськи, однак було б перебільшенням вважати, що вони говорили літературною мовою, якою писали автори з підросійської України і яка теоретично вважалася взірцем для всієї України. На думку Ю. Шевельова, «і до тодішньої мови підросійської України термін «літературна» варто прикладати з великим застереженням. Існували певні правила вжитку, але вони не були унормовані, ні навіть грунтовно описані, не було й авторитету, що міг би їх запровадити» ${ }^{16}$.

13 Огієнко I. (Митрополит Іларіон). Історія української літературної мови. Либідь, 1995. С. 178; Мозер М. Причинки до історії української мови. Харків : Харківське історико-філологічне товариство, 2008. XVI, С. 602-626, 641-667; Мозер М. Історія української мови. Київ, 2018. С. 20.

4 Шевельов Ю. Українська мова в першій половині двадцятого століття (1900-1941): Стан і статус. Чернівці : Рута, 1998. С. 18.

15 Русанівський В. Історія української літературної мови. Київ : Артек, 2001. С. $229,232$.

16 Шевельов Ю. Українська мова в першій половині двадцятого століття (1900-1941): Стан і статус. Чернівці : Рута, 1998. С. 20. 
У другій половині XIX ст. визначною подією в Галичині стала поява великої кількості граматик - підручників для середніх та народних шкіл або ж посібників для самостійного вивчення мови ${ }^{17}$, зокрема побачили світ «Граматика руского языка» (1864) М. Осадци, «Мала грамматика языка руского» (1865) Г. Шашкевича, «Методична граматика языка мало-руского» (1865) П. Дячана, «Граматика руского языка» (1873) О. Партицького, «Граматика руского языка для шкоิль середнихъ» (1889) О. Огоновського, «Руска граматика» (1893) С. Смаль-Стоцького та Ф. Гартнера, «Методична граматика української мови» (1900) В. Коцовського та І. Огоновського тощо. Варто зазначити, що «Руска граматика» (1893) С. Смаль-Стоцького, Ф. Гартнера стала знаковою працею для Галичини, оскільки «наближалася до норм Центральної України, зокрема в запровадженні так званого фонетичного письма, хоч і з чималою кількістю місцевих особливостей, i була затверджена після запеклого нерозбірливого в засобах спротиву австрійським Міністерством освіти, потрапила до шкіл щойно 1893 р., попереджена в лексикології першим великим словником Е. Желехівського - 1886 р.» ${ }^{18}$. Зауважмо, що граматика мала значний успіх і її було неодноразово перевидано, зокрема 1907, 1914, 1928 pp.

У «Граматиці» репрезентовано низку особливостей, які утверджували західноукраїнський варіант літературної мови, однак лише у виданні 1914 p. на противагу було представлено східноукраїнські норми. До прикладу, при словозміні в іменниках чоловічого роду «відм. 3 одн. кінчить ся правильно на -ови (на Українї oвi). Окрім того, подибуєть ся деколи закінченє -y Богу, духу (побіч Богови, духови)»; «на -еви, -єви (на Україні -еві, -єві): учителеви, добродієви» ${ }^{19}$. Особливістю відмінювання іменників жіночого роду «шелестівкової відміни» є Р.в., Д.в. однини - флексія -и (части), О.в. однини - закінчення -ию, -ю (частию, частю), Р.в. множини - -ий (частий), однак «в відм. 2-ім, 3-ім одн. і 1 мн. уживають закінчення -i: ночi, печі, подорожі, миші» ${ }^{20}$. Іменники середнього роду «мягкої відміни» мають закінчення «на -е, -є (писанє, поясненє, житє). «У всїх тих іменників подибуємо на Україні, в 1-ім відм. одн. замість $-\epsilon(-e)$ закінченє -я (-a) після анальогії 1-го відм. іменників ягня, лоша і т. д.: життя, безвіддя, колосся» ${ }^{21}$.

17 Лесюк М. Становлення і розвиток української літературної мови в Галичині : монографія. Івано-Франківськ: Місто НВ, 2014.

18 Шевельов Ю. Українська мова в першій половині двадцятого століття (1900-1941): Стан і статус. Чернівці : Рута, 1998. С. 21.

${ }^{19}$ Смаль-Стоцький С., Гартнер Ф. Граматика руської мови. Вид. 3. Відень, 1914. C. 67,71 .

\footnotetext{
${ }^{20}$ Там само. С. 75 .

${ }^{21}$ Там само. C. 78.
} 
Натомість у «Методичній граматиці української мови» (1900) В. Коцовський та І. Огоновський допускають в іменниках чоловічого роду у Д.в. однини закінчення «еви, єви (учителеви, добродієви); по співзвуку змягченім і по $p$ може бути ови та еви (товаришови, лікарови або товаритеви, лікареви); $y$, ю: Богови, Богу, монастиреви, монастирю»; в О.в. одн. - «ем (учителем); по змягченій і по $p$ буває ом або ем (товаришом і товаришем); закінчені на й мають $є м$ (добродієм); в О.в. жіночого роду - закінчення -ию та -ю: частию, частю, любовю; кровию, кровю» 22 . Учені вказали, що в Р.в. множини деякі іменники чоловічого роду мають замість закінчення ів, їв - ий: гостий, коний, гроший; жіночого роду - ий-ів: частий, піснїв, ночів. «В III, VI i VII-ім відмінку є побіч закінчень -ям (ам), -ями (-ами), -ях (-ах) також -ем, -ьми (-ми), -ех: грудем, грудьми, пригошми, в грудех» ${ }^{23}$.

На початку XX ст. виникають граматики, які репрезентують східноукраїнський варіант літературної мови - «Українська граматика» (1917) Є. Тимченка, «Грамматика украінського язика» (1913) I. НечуйЛевицького, «Граматика української мови» (1921) В. Сімовича тощо.
B
«Українській
граматиці»
(1917)
Є. Тимченка чітко прослідковується в іменниках чол.роду в Д.в. однини закінчення -овi, евi, -єві (братові, слухачеві, краєві), -y. «Пануюча форма на -ові (-еві); кінцівка $y$ вживається переважно при збігу двох дативів: пану Иванові; у родовому відмінку множини -iв, -ей (-ьц̆): панів, тестів, але коней, громей, гостей, людей» ${ }^{24}$. В іменниках середнього роду фіксуємо «бажання, бажанє, бажаннє; О.в. - флексії -ям, -єм: бажанням, бажанєм, бажанням» ${ }^{25}$. Для іменників жіночого роду в Р.в., Д.в., М.в. одн. - речі, тіни (тіні); О.одн. - річчу, тінню, частю, вдячністю. У Н., З.в. множини - речі, тіні, части, вдячности; у Р.мн. - речей, mіней, частей, вдячностей ${ }^{26}$. І. Нечуй-Левицький у «Грамматиці украінського язика» (1913) в основному репрезентує таку ж словозміну іменників, однак в іменниках жіночого роду в множині пропонує закінчення -ів. «Усі загалом слова жіночого роду 2 склоніння, що закінчуються на $-b$, в част. падіжі множ. числа мають закінчення -ів:

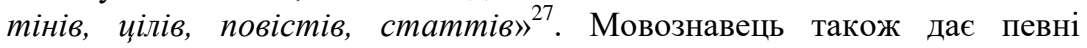

22 Коцовський В., Огоновський I. Методична граматика української мови. 4-те, попр. вид. Вінніпег : Накладом української книгарні, 1900. С. 22, 28.

${ }^{23}$ Там само. С. $23,28$.

24 Тимченко С. Українська граматика. 2-ге вид. Київ : Друкарня Ун-ту св. Володимира Акц. Т-ва друк. і видавн. діла, 1917. С. 96, 98.

${ }^{25}$ Там само. С. 100.

${ }^{26}$ Там само. С. 107-108.

27 Нечуй-Левіцький I. Грамматика Украінського язика. Частка І. Етимологія. Київ : Друкарня Другої Артілі, 1913. С. 25. 
зауваги: «Не можна писать слова жіночого роду з закінченням на $і$ я, змінюючи ія на ия, як пишуть в Галичині: нация, поезия, резиденция, традиция, бо це польські закінчення» ${ }^{28}$.

Навіть такий короткий аналіз окремих граматичних явищ у працях, надрукованих наприкінці XIX - на початку XX ст. на теренах Галичини та Наддніпрянщини, репрезентує різнорідність форм, що було спровоковано саме наявністю двох варіантів літературної мови. Заслуговує на увагу також i те, що в граматиках у межах одного варіанта (західно- чи східноукраїнського) теж не було чіткої, виробленої системи.

\section{2. Мова творів I. Франка:}

\section{у пошуках сдиної української літературної норми}

Література Галичини 1848-1852 рр. характеризувалася «деякими спробами наблизитися до народної мови», однак на чисту народну мову перейти не змогла, а 50-ті роки вже визначаються цілковитим засиллям «язичія», якому сприяв «москвофільський» рух. Чітке визначення цьому мовному феномену дає О. Муромцева: це «один із типів штучно витвореної книжної мови в Західній Україні XIX ст. Назва виникла в полеміці з прихильниками язичія і мала зневажливий відтінок. В основі язичія була старослов'янська мова 3 домішками елементів російської і староукраїнської мов, західноукраїнських діалектів. В язичії застосовувалася кирилиця та історико-етимологічний правопис. Підтримувалося «москвофілами», які гадали в такий спосіб досягти т.зв. мовної єдності з Росією, а також тими, хто заперечував здатність народної («мужичої») мови піднятися до рівня літературної» ${ }^{29}$.

Одночасно 3 «москвофільством» у 60 -х роках XIX ст. в Галичині зародилося т.зв. «народовство», яке орієнтувалося на народну мову, не визнаючи «язичія». Прихильники цієї течії писали свої твори місцевим діалектом, хоч такі перші спроби зробили автори «Русалки Дністрової»»! ${ }^{30}$.

Власне зі 70-х років XIX ст. в українську літературу приходить нове покоління, серед них - й I. Франко, який увійшов у консервативне галицьке письменство 3 уже вповні сформованою «духовною

${ }^{28}$ Нечуй-Левіцький I. Грамматика Украінського язика. Частка I. Етимологія. Київ : Друкарня Другої Артілі, 1913. С. 26.

29 Муромцева О.Г. Язичіє. Украӥнська мова. Енциклопедія / ред. Кол.: В.М. Русанівський, О.О. Тараненко (співголови). 2-ге вид., випр. і доп. Київ : «Українська енциклопедія» ім. М. Бажана. 2004. С. 813.

30 Ковалів П. Значення І. Франка в розвитку літературної мови Галичини. Записки НTШ. T. CLXXXIV: Іван Франко. Збірник доповідей для відзначення 110-річчя народин і 50-річчя смерти Івана Франка. 1968. Ч. II. С. 6. 
фізіономією»: 3 естетичною програмою новочасної літератури, із власним розумінням іiі завдань $\mathrm{i}$ тематичних пріоритетів, 3 оригінальним трактуванням авторської концепції та індивідуального стилю, зрештою, з новою концепцією реальної мови, що в сумі мали б прорвати естетичну, тематичну й мовностилістичну блокаду млявої літературної практики й відкрити шлях всеосяжному мистецькому експерименту $^{31}$. Дослідниця Франкового наукового стилю В. Березянська зазначила, що «своїм лексиконом, унікальним як у кількісному (номінативному), так і якісному (семантичному) аспектах, характером сприйняття й омовлення дійсності вчений збагачував тогочасні не лише «канонічні» науки (літературознавство, мовознавство, історію, правознавство), а й «неканонічні» (психологію, політекономію, філософію тощо)» ${ }^{32}$.

Однак перші твори І. Франка позначилися мішаниною української, російської і польської мов, оскільки друкувалися в москвофільському часописі «Другъ». Користувався поет також i діалектними морфологічними формами. Згодом, приєднавшись до народовців, він орієнтувався лише на українську мову. Щоправда, «це не була літературна мова, що усталилася на той час на Наддніпрянщині» ${ }^{33}$, це була, власне, «ще тільки сировина, що 3 неї треба було створити літературну мову як повноцінне знаряддя культурного життя українського народу» ${ }^{34}$. Варто зауважити, що тоді нелегко «було зорієнтуватися, яка лексема має право на існування й використання, оскільки українська мова на той час ще не була унормована, словників, які можна було б вважати нормативними (крім словника Желехівського), теж не було» ${ }^{35}$. Майже всі редакції, видання i видавництва були під сильним впливом москвофілів; саме тому основною ідеєю І. Франка в ранній період його творчості була боротьба за чистоту української літературної мови ${ }^{36}$. Відповідно, у 80 -их роках I. Франко ще більше удосконалює свою мову, при цьому виправляючи

31 Ціхоцький І.Л. Мова прози Івана Франка (стилістичні новації). Львів : Вид. центр ЛНУ ім. І. Франка, 2006. С. 6.

${ }^{32}$ Березянська В. Іван Франко і проблема становлення української наукової мови. Проблеми гуманітарних наук. Філологія. 2013. Вип. 32. С. 12-13. C. 252.

33 Русанівський В. Історія української літературної мови. Київ : Артек, 2001. C. 152.

Чапленко В. Історія нової української літературної мови. Нью-Йорк, 1970.

35 Лесюк М. Становлення і розвиток української літературної мови в Галичині : монографія. Івано-Франківськ : Місто НВ, 2014. С. 617.

36 Ковалів П. Значення I. Франка в розвитку літературної мови Галичини. Записки НТШ. T. CLXXXIV: Іван Франко. Збірник доповідей для відзначення 110-річчя народин і 50-річчя смерти Івана Франка. 1968. Ч. II. С. 8. 
мову своїх попередніх творів, зокрема і поетичних. Про це поет зазначив у передмові до другого видання збірки «3 вершин і низин» (1893): «Я користуюся авторським правом і, не тикаючи основної думки, підправляв мову, котроі виробленє до ступня мови літературноі за остатніх 20 літ все ж значно посунулось наперед, може й не без моєї скромної підмоги. Що в моїх давнійших віршах мова не все чиста, се ще тим легше зрозуміти, що я переходив деякі такі ступні розвитку (а хто в Галичині не переходив йіх в тім часі!), де панувало намаганє притлумити почутє живоі, чистоі народньоі мови, котре $з$ малку ще було у мене сильно розвите. На мні в мінятурі повторилось те, що в великім розмірі бачимо на всій галицько-руській літературі: школа, граматики і спори язикові прибили і закаламутили чистоту народньоі мови» ${ }^{37}$. Варто зазначити, що поет влучно також і «кував слова, головно в ранній творчості, або й запроваджував такі слова, що прикметні наддністрянському говорові: бездух (трус, боязуз), вмір (загибель), зговір (умова), повість (розповідь), почин (початок) тощо» ${ }^{38}$.

I. Франко черпав слова з місцевої говірки, з мови інших українських письменників, в основному східних, що зумовлено його поїздками до Києва. Стаючи на шлях зближення мови галичан до наддніпрянців, I. Франко приймає щораз більше панівних у літературній мові «східних елементів лексичних, морфологічних, синтаксичних, а крім того, впроваджує у свою мову багато ознак західноукраїнських, які за його прикладом стають загальноукраїнські, літературні» ${ }^{39}$. Проаналізуймо уривки поезій:

\begin{tabular}{|c|c|}
\hline \multicolumn{2}{|c|}{ «3 вершин і низин» } \\
\hline 1887 & 1893 \\
\hline $\begin{array}{l}\text { В груди радісно бєсь здоровая, } \\
\text { Молодая кров, } \\
\text { Так і грудь землі дише-двигаєсь } \\
\text { Силой чудною, оживущою } \\
\text { (5) }\end{array}$ & $\begin{array}{l}\text { В груди радісно бєсь здоровая, } \\
\text { Молодая кров, } \\
\text { Так і грудь землі диха-двигаєсь } \\
\text { Силов дивною, оживущою } \\
\text { (12) }\end{array}$ \\
\hline $\begin{array}{l}\text { Сійте! на пухку, на живу рілю } \\
\text { Впадуть сімена мислі вашоі! } \\
\text { (6) }\end{array}$ & $\begin{array}{l}\text { Сійте! на пухку, на живу рілю } \\
\text { Впадуть сімена думки вашоі! } \\
\text { (13) }\end{array}$ \\
\hline
\end{tabular}

37 Франко I. 3 вершин і низин. Переднє слово. Друге, доповн. виданє. Львів, накладом Ольги Франко, 1893. С. 4-5.

38 Лев В. Участь І. Франка в творбі української літературної мови. Записки HTШ. T. CLXVI. 1957. C. 129.

39 Лев В. Західно-українські признаки мови Івана Франка в його ранніх творах. Рідне слово. 1946. Ч. 6. С. 72. 


\begin{tabular}{|c|c|}
\hline \multicolumn{2}{|c|}{ 《3 вершин і низин» } \\
\hline 1887 & 1893 \\
\hline $\begin{array}{l}\text { Лице небесне прояснилось } \\
\text { I блеском роскоші облилось... } \\
\text { (11) }\end{array}$ & $\begin{array}{l}\text { Лице небесне прояснилось } \\
\text { І блиском роскоші облилось... } \\
\text { (11) }\end{array}$ \\
\hline Вчора гнив мов Лазар & Вчора тлів мов Лазар \\
\hline В горя домовині - & В горя домовині - \\
\hline Що ж се за нова зоря & Що ж се за нова зоря \\
\hline Мні заблисла нині? & Міні блисла нині? \\
\hline Чудний звук мя зве кудись & Дивний голос мя кудись \\
\hline $\begin{array}{l}\text { Кличе -тут то, ген то: } \\
\text { «Встань, прокинь ся, } \\
\text { пробудись!» }\end{array}$ & $\begin{array}{l}\text { Кличе -тут то, ген то: } \\
\text { «Встань, прокинь ся, } \\
\text { пробудись!» }\end{array}$ \\
\hline (19) & (21) \\
\hline
\end{tabular}

Мовознавець В. Лев, досліджуючи мову ранніх творів І. Франка, звернув увагу на особливості відмінювання іменників. «Серед деклінаційних форм цікаві у Франка прикметні галицьким говіркам закінчення іменників чоловічого роду у Дав. одн.: товаришу і Місц. одн.: товаришом. У середньому роді іменник приголосівкової відміни дістає закінчення -ом: плечом та -ів у род. множ.: з віконців. 3-поміж форм жіночого роду в найбільшій кількості появляється закінчення одн. -ов, -ев, яким поет послуговується в поезії і часто ставить його поруч літературного -ою, -ею» ${ }^{40}$. Щодо прикметників, то варто згадати про суфікс вищого ступеня порівняння -ійший: тривкійша. Натомість серед займенників багато форм, які притаманні галицьким говіркам: ми, мя, тя, в мні тощо. Аналіз лексики поетичних творів письменника засвідчує, що в ії складі є немало слів, запозичених із російської чи старослов'янської мов, які, звичайно, ні в часи, коли він писав, ні в новітні часи не стали нормативними для української мови. «Водночас $\epsilon$ значна частина слів, які відрізняються від питомих українських лише словотворчими афіксами, морфологічною будовою, фонетичним оформленням (що відбито на письмі), граматичними ознаками (різний граматичний рід тощо). Дуже часто вживані і в прозових, і в поетичних творах письменника $є$ активні дієприкметники минулого часу, що теж не $\epsilon$ нормативними для української мови» ${ }^{41}$.

40 Лев В. Західно-українські признаки мови Івана Франка в його ранніх творах. Рідне слово. 1946. Ч. 6. С. 70.

41 Лесюк М. Становлення і розвиток української літературної мови в Галичині : монографія. Івано-Франківськ : Місто НВ, 2014. С. 614. 
У пізніших поетичних творах, зокрема у збірці «Зів’яле листє», виявляємо вдосконалення мови I. Франка, що зумовлено титанічною працею над мовою своїх творів і «послідовних редакцій цієї мови в напрямі наближення іiі до великоукраїнської» ${ }^{42}$.

\begin{tabular}{|c|c|}
\hline \multicolumn{2}{|c|}{ «Зів’яле листє» } \\
\hline 1893 & 1896 \\
\hline Я питав про щось таке & Я питав про щось таке \\
\hline Що й не стоїло питать (95) & Що й не варт було питать (15) \\
\hline $\begin{array}{l}\text { Tи найтайнішеє бажанє, щзо } \\
\text { поров }\end{array}$ & $\begin{array}{l}\text { Ти найтайнійший той порив, щзо } \\
\text { бурить кров, }\end{array}$ \\
\hline $\begin{array}{l}\text { Підносить грудь, та ба, ніколи не } \\
\text { сповнить ся (95) }\end{array}$ & $\begin{array}{l}\text { Підносить грудь, та ба - ніколи } \\
\text { не сповнить ся (17) }\end{array}$ \\
\hline $\begin{array}{l}\text { Ти подвиг славний той, що я-б на } \\
\text { него йшов, }\end{array}$ & $\begin{array}{l}\text { Ти славний подвиг той, що я-б на } \\
\text { него йшов, }\end{array}$ \\
\hline $\begin{array}{l}\text { Слиб віра в мні була й могучая } \\
\text { десниця (96) }\end{array}$ & $\begin{array}{l}\text { Коб віра сильная й могучая } \\
\text { десниця (17) }\end{array}$ \\
\hline $\begin{array}{l}\text { А чень утечу я від лютого болю, } \\
\text { Що серце міні розрива (98) }\end{array}$ & $\begin{array}{l}\text { А чень утечу я від лютого болю, } \\
\text { Що серце моє розрива (22) }\end{array}$ \\
\hline Та боюсь за тебе дуже, & Та боюсь за тебе дуже, \\
\hline $\begin{array}{l}\text { Бо люоов, то мстивий оог: } \\
\text { Як одно } \epsilon i \text { зневажить, }\end{array}$ & $\begin{array}{l}\text { ьо люоов, то мстивий оог: } \\
\text { Як одно йійі зневажить, }\end{array}$ \\
\hline Любить мстить ся на обох (102) & Любить мстить ся на обох (31) \\
\hline
\end{tabular}

Паралельне використання форм західноукраїнського та східноукраїнського варіантів літературної мови репрезентовано в збірках «Мій ізмарагд» та «Давнє і нове»: житя-житє, пролог-прольог, людей-людий та ін.

\begin{tabular}{|l|l|}
\hline \multicolumn{1}{|c|}{ «Мій ізмарагд» } & \multicolumn{1}{|c|}{ «Давнє і нове» } \\
\hline \multicolumn{1}{|c|}{1898} & \multicolumn{1}{|c|}{1911} \\
\hline Украіно, моя сердечна нене! & Украіно, моя сердечна нене! \\
Не лай мене, стражденна, & Не лай мене, стражденна, \\
незабута, & незабута, \\
Що не дало моє житя злиденне & Що не дало моє житє злиденне \\
Того, що ждати ти могла від & Того, що ждати ти могла від \\
мене! (4) & мене! (14) \\
\hline
\end{tabular}

\footnotetext{
${ }^{42}$ Шерех Ю. Мовна дискусія 1891-1893 років і участь у ній Івана Франка. Рідне слово. 1946. Ч. 6. С. 79.
} 


\begin{tabular}{|c|c|}
\hline «Мій ізмарагд» & «Давнє і нове» \\
\hline 1898 & 1911 \\
\hline $\begin{array}{l}\text { Мій поклик: праця, шастє і } \\
\text { свобода, } \\
\text { Я є мужик, пролог, не епілог } \\
\text { (12) }\end{array}$ & $\begin{array}{l}\text { Мій поклик: праця, шастє і } \\
\text { свобода, } \\
\text { Я є мужик, прольог, не епільог } \\
\text { (17) }\end{array}$ \\
\hline Та Аглая, котроі надземна краса & Та Аглая, котроі надземна краса \\
\hline Звеселяє людей і самі небеса. & Звеселяс людий і самі небеса. \\
\hline Та йідких єi слів і шпаркого ума & Та ̈̈дких ї̈ слів і шпаркого ума \\
\hline $\begin{array}{l}\text { Всї бояли ся, навіть цариця сама } \\
\text { (62) }\end{array}$ & $\begin{array}{l}\text { Всї бояли ся, навіть цариця сама } \\
\text { (68) }\end{array}$ \\
\hline $\begin{array}{l}\text { Сусід мене } c \text { слізми благає } \\
\text { На млин пустити воду знов, } \\
\text { Бо сеж увесь єго прожиток, } \\
\text { Єго й дітей, пятьох голов } \\
(89) .\end{array}$ & $\begin{array}{l}\text { Сусїд мене з слїзми благає } \\
\text { На млин пустити воду знов, } \\
\text { Бо се-ж увесь його прожиток, } \\
\text { Його й дїтий, пятьох голов } \\
(100) \text {. }\end{array}$ \\
\hline
\end{tabular}

Не применшуючи літературної вартості Франкових творів, як зауважує І. Ціхоцький, чимало дослідників ставило під сумнів мовну вартість його текстів. «Полеміка щодо Франкової мови i мови галицького письменства в цілому не була новою - початки іiі віднаходимо в «пуристичних» писаннях В. Чайченка (Б. Грінченка)» ${ }^{43}$, який звинувачував галичан у надмірному захопленні «полонізмами», «москалізмами», «провінціалізмами» і «рутенізмами» (стаття «Галицькі вірші» Б. Грінченка, 1891). Власне саме це й спровокувало мовну дискусію 1891-1892 рр., участь у якій взяли з боку східних українців Б. Грінченко, М. Школиченко, А. Кримський, а з боку галицьких українців - I. Франко, I. Кокорудз, I. Верхратський, О. Маковей. Східноукраїнські письменники висунули низку звинуваченьаргументів: «1) Галичина не може претендувати на створення української літературної мови, бо вона становить лише малу частину України. Не може бути мови галицько-української, як не може бути мови херсонсько-української; 2) створена в Галичині книжна мова - це макаронічне «язичіє», незрозуміле більшості українського народу; 3) ця мова відійшла від мови творів Котляревського, Квітки-Основ'яненка,

43 Ціхоцький І.Л. Мова прози Івана Франка (стилістичні новаціі). Львів : Вид. центр ЛНУ ім. І. Франка, 2006. С. 7. 
Шевченка» ${ }^{44}$. Зазначмо, що за винятком А. Кримського, І. Кокорудза $\mathrm{i}$ частково I. Франка, дискусія велася нефахово, спираючись більш на емоційні принципіи, ніж на раціональні. «Дискутанти ставили на перше місце свою льокальну говіркову мову як основу для літературної, а деколи й перевагу своєї говірки над іншою» ${ }^{45}$. Однак ця дискусія мала надзвичайно велике значення в розвитку української літературної мови загалом та в творчості I. Франка зокрема, оскільки вона не лише підняла на поверхню ті процеси, які відбувалися в літературній мові, а й змусила українську інтелігенцію хоч частково їх усвідомити. Це була «пересторога галичанам щодо їхніх екстремізмів у запровадженні галицьких мовних елементів до літературної мови, а великоукраїнцям щодо нетолерантного ставлення їх до галицьких впливів на літературну мову» ${ }^{46}$. Хоч дискусія і не змінила напряму розвитку літературної мови, однак іï учасники почали більше звертати увагу на мову Великої України. І. Франко, взявши в ній участь, виступив проти надання переваги в українській літературній мові східно-українським елементам, однак був за те, щоби використовувати всі «відтінки, котрих годі не бачити, на котрих тяжко гніватися» ${ }^{47}$. У статті «Говоримо про вовка - скажімо і за вовка» (1891) поет висловив важливу думку: «Мені бажалось би своїми увагами докинути цеглинку до взаємного порозуміння між українцями і галичанами на полі язиковім і таким способом причинитися до полагодження одного дуже важного питання - будущої єдності і одноцільності нашої літературної мови, будущої, повторяю, бо тепер ми ще ії не маємо і задля, звісно, дуже важних причин мати не можемо» ${ }^{48}$. У питанні єдності літературної мови І. Франко виходив із того, що вона $\epsilon$ важливим об'єднувальним, консолідувальним чинником будь-якої нації, а іiі відсутність пояснював відповідними історичними обставинами «Галичина 1772 р. перейшла під панування Австрії і втягнена була в культурний круг, дуже відмінний від того, в який втягнена була решта України» ${ }^{49}$. Слушно зауважив В. Грещук, що «для тогочасної України, яка впродовж кількох століть була поділена і входила до складу різних

44 Лесюк М. Становлення і розвиток української літературної мови в Галичині : монографія. Івано-Франківськ : Місто НВ, 2014. С. 22-23.

45 Лев В. Участь І. Франка в творбі української літературної мови. Записки HTU. T. CLXVI. 1957. C. 130.

${ }^{46}$ Шерех Ю. Мовна дискусія 1891-1893 років і участь у ній Івана Франка. Рідне слово. 1946. Ч. 6. С. 79.

47 Чапленко В. Історія нової української літературної мови. Нью-Йорк, 1970. C. 153 .

${ }^{48}$ Франко І. Говоримо на вовка - скажімо і за вовка. Франко I. Зібрання творів у 50-ти томах. Т. 28. Київ : Наукова думка, 1980. С. 171.

${ }^{49}$ Там само. С. 174. 
держав, проблема літературної мови, спільної для всіх українців, була особливо актуальною і значущою. Та обставина, що Наддніпрянщина, Галичина, Закарпаття тривалий час, власне від занепаду ГалицькоВолинського князівства, не становили собою державної, політичної цілості, позначилося на культурі і мові українців» ${ }^{50}$. І. Франко, окреслюючи причини й історію втрати українцями державності, зазначив виняткову роль мови, яка, незважаючи на різні несприятливі умови, зберігає єдність нації в просторі і часі.

Учений надзвичайно глибоко розумів вагу соборної літературної мови та мав чітку позицію щодо важливості всіх говорів. Але згодом, за словами В. Русанівського, «вступивши в ХХ ст., змінив свою думку, зрозумівши, що без оволодіння мовою Котляревського і Шевченка, жоден письменник у нову українську літературу не ввійде» ${ }^{51}$.

Над культурою своєї мови Франко спочатку працював мало, пишучи звичайною галицькою говіркою, але, як зазначив I. Огієнко, «Драгоманова наука про літературну мову проте не пішла Франкові на марне, а він був його вірним учнем, і пізніш Франко рішуче повернув у своїй мові на схід і став більше працювати над своєю мовою» ${ }^{52}$.

Каменяр обстоював зближення мови галицьких письменників $\mathrm{i}$ літературної мови Східної України. У передмові до третього видання «Лис Микита» (1902) поет зазначив: «Я дбав про те, щоб мова моєї перерібки, не тратячи основного характеру галицько-руського нарічя, все таки не разила й Українців і наближувала ся до тої спільної Галичанам і Українцям лїтературної української мови, якої витворенє так дуже потрібне для нашого суцїльного лїтературного розвою» ${ }^{53}$. Дослідник В. Лев навів приклади виправлення мови, які ілюструють цей процес у розвитку Франкової мови: високообразований високоосвічений, висказувались - висловлювались, звісний - відомий, знакомий - знайомий, наболівший - наболілий, писатель - письменник, помочи - помогти, противно - навпаки, той, сей - цеей, та прецінь - та все таки, хоть - хоч тощо ${ }^{54}$.

${ }^{50}$ Грещук В. Роль Івана Франка у формуванні єдиної української літературної мови. Вісник Наукового товариства ім. Шевченка. Чис. 2. Івано-Франківськ : [б.в.], 2007. C. 29.

C. 252 .

51 Русанівський В. Історія української літературної мови. Київ : Артек, 2001.

${ }_{52}$ Огієнко І. (Митрополит Іларіон). Історія української літературної мови. Либідь, 1995. С. 183.

53 Франко I. Хто такий Лис і відки родом? Франко I. Лис Микита. Третє поправлене видання. Львів : Накладом Руського Товариства педагогічного, 1902. C. XV.

54 Лев В. Участь I. Франка в творбі української літературної мови. Записки HTH. T. CLXVI. 1957. C. 128. 
У розвідці «Літературна мова і діялєкти» (1907) І. Франко чітко окреслив своє бачення єдиної української літературної мови, при цьому розуміючи, що пріоритет треба віддати східноукраїнському варіанту. «Наша лїтературна мова в остатнїх десятилїтях таки значно виробила ся. Кождий, хто брав ся писати тою мовою, на скілько черпав із книжкової традиції, мусїв черпати зачинати від Котляревського, Квітки, Шевченка, Марка Вовчка, Нечуя-Левицького, мусить бачити, що тут, у мові тих письменників, лежить основа того типу, яким мусить явити ся вироблена лїтературна мова всїх Українцїв. Уже хоча би тому, що та мова на величезному просторі від Харкова до Камянця Подільського виявляла таку одностайність, такий брак різкійших відмін, який в повнї відповідав українському національному типови, також «вимішаному» і вирівняному в цїлій масі, як мало котрий подібний тип у сьвітї. I от кождий, Галичанин чи Українець, хто бажає друкованим словом промовити до найбільшої маси українського народу, мусить уживати мови тої найбільшої маси, а до того мови виробленої найбільшим числом талановитих та популярних письменників» ${ }^{55}$. Відповідно, І. Франко став систематично наближати свою мову до наддніпрянської, однак вважав, що «кожна лїтературна мова доти жива і здібна до житя, доки має можливість 3 одного боку всисати в себе всї культурні елєменти сучасности, значить, збогачувати ся новими термінами, та висловами відповідними до прогресу сучасної цівілїзації, не тратячи при тім свойого основного типу і не переходячи в жаргон якоїсь спеціяльної верстви чи купи людий, а з другого боку доки має тенденцію збогачувати ся чимраз новими елєментами 3 питомого народного житя і з відмін та діялєктів народного говору» ${ }^{56}$. Письменник ставився дуже критично i до себе, i до мови, яка функціонувала в Галичині, зазначаючи, що «у нас в Галичині, де друковано і писано довжелезний ряд граматик від Могильницького до Огоновського, де ті граматики товкмачено тисячам інтелїгентних дїтий у голови на шкільній лаві, все таки знає нашої мови дуже мало, язик поплутаний і запоганений, язикове почутє у всїх, що пишуть і говорять нашою мовою, зовсїм затемнене і затуплене» ${ }^{57}$. Ось тому, вважає М. Лесюк, І. Франко й орієнтувався на мову письменників із Великої України, «хоча там також тривалий час українська мова була під

55 Франко І. Літературна мова і діялєкти. Літературно-науковий вісник. 1907. T. XXXVII. Кн. 2. C. 226.

\footnotetext{
${ }^{56}$ Там само.

${ }^{57}$ Там само. С. 225.
} 
забороною, не була впорядкована i кожен письменник також використовував її на власний розсуд» 58 .

Мова І. Франка переживала кілька етапів розвитку, постійне удосконалення та кристалізацію, набувала ознак єдиної української літературної мови. Влучно згодом зауважив В. Чапленко, вказавши, що тенденція до очищення літературної мови «від вузьких галицьких льокалізмів мала велике значення взагалі, бо це визначало шлях, яким повинні були йти пізніші галицькі діячі в царині українського мовотворення» ${ }^{59}$. I хоч I. Франко так і не виробив для себе «зразкової мови», однак «важливість літературної мови він розумів і свідомо йшов до неї» ${ }^{60}$. Поет перший на Західній Україні свідомо став на шлях іiі уніфікації, оскільки «орієнтуючись на Східню Україну, не забував i своєї рідної говірки чи говірок - як невичерпного джерела живлення української літературної мови» ${ }^{61}$. У цьому й полягає заслуга I. Франка в історії української літературної мови взагалі і в Галичині зокрема. За словами Ю. Шевельова, «витворювався синтетичний характер нової українсько літературної мови: при незаперечній центральноукраїнській говірковій основі, вона ввібрала в себе і чимало елементів периферійних - східних, південних, меншою мірою - північних, а найбільше - західних» ${ }^{62}$.

\section{ВИСНОВКИ}

Отже, І. Франко відіграв надзвичайно велику роль як у розвитку літературної мови Галичини, так і в боротьбі за єдину літературну мову для всієї України. Учений не тільки удосконалював свою мову відповідно до розвитку своєї літературної творчості, не тільки виправляв мову своїх ранніх творів, а також дбав про вироблення мови публіцистичної та наукової. Зауважмо, що на формування його індивідуального мовного стилю вплинули: 1) розмовно-народна мова південно-західного наріччя; 2) західноукраїнська літературно-мовна традиція; 3) літературно-мовна традиція східної України.

58 Лесюк М. Становлення і розвиток української літературної мови в Галичині: монографія. Івано-Франківськ : Місто НВ, 2014. С. 620.

59 Чапленко В. Історія нової української літературної мови. Нью-Йорк, 1970. C. 155 .

${ }^{60}$ Огієнко І. (Митрополит Іларіон). Історія української літературної мови. Либідь, 1995. С. 178.

${ }^{61}$ Ковалів П. Значення І. Франка в розвитку літературної мови Галичини. Записки НТШ. Т. CLXXXIV: Іван Франко. Збірник доповідей для відзначення 110-річчя народин і 50-річчя смерти Івана Франка. 1968. Ч. II. С. 12.

62 Шевельов Ю. Нарис сучасної української літературної мови та інші лінгвістичні студії (1947-1953 рр.) / упорядк.: Л. Белея, Л. Нуждак. Київ : Темпора, 2012. C. 455. 


\section{АНОТАЦІЯ}

Запропонована розвідка містить детальний аналіз спроби кодифікації української літературної мови наприкінці XIX - на початку XX ст. крізь призму постаті I. Франка. Зокрема встановлено, що українська літературна мова 3 кінця XVIII ст. розвивалася під впливом двох літературно-мовних традицій - східноукраїнської (наддніпрянської) та західноукраїнської (наддністрянської, або галицької). У дослідженні прослідковано передумови виникнення двох варіантів літературної мови: подано детальний огляд причин, історичних подій та політичних процесів, які цьому передували; здійснено огляд граматичних праць Галичини та Наддніпрянщини кінця XIX - початку XX ст., а також проаналізовано та зіставлено окремі граматичні явища.

У цій праці представлено детальний аналіз ролі I. Франка в унормуванні української літературної мови, а саме: репрезентовано основні етапи розвитку мови письменника, проаналізовано особливості мови ранніх та пізніших його поетичних творів (граматичні, стилістичні, лексичні) та прослідковано послідовність редакції мови поета в бік східноукраїнського варіанта. Також висвітлено причини та основні тези мовної дискусії 1891-1892 pp. і їі вплив на подальший розвиток єдиної української літературної мови загалом та на творчість I. Франка зокрема.

\section{ЛІТЕРАТУРА}

1. Березянська В. Іван Франко і проблема становлення української наукової мови. Проблеми гуманітарних наук. Філологія. 2013. Вип. 32. C. $4-15$.

2. Гірняк С.П. Роль соціолекту інтелігенції східної Галичини у формуванні норм української літературної мови (кінець XIX - перша половина XX ст.) : дис. ... докт. філол. наук : 10.02.01 «Українська мова». Дрогобицький державний педагогічний університет імені Івана Франка. Дрогобич, 2018. 723 с.

3. Грещук В. Роль Івана Франка у формуванні єдиної української літературної мови. Вісник Наукового товариства ім. Шевченка. Чис. 2. Івано-Франківськ : [б.в.], 2007. С. 29-37. URL: http://lib.if.ua/ franko/1311683953.html

4. Гримашевич Г. Концепція взаємодії літературної мови та діалектів у мовознавчій спадщині Івана Франка. ВолиньЖитомирщина. 2006. № 15. С. 209-215.

5. Єрмоленко С.Я. Літературна мова. Енииклопедія / ред. кол.: В.М. Русанівський, О.О. Тараненко (співголови). 2-ге вид., випр. і доп. Київ : «Українська енциклопедія» ім. М. Бажана. 2004. С. 318-320. 
6. Жилко Ф.Т. Мова Івана Франка (Лекція для студентів-заочників факультету мови і літератури). Київ-Львів : Радянська школа, 1949. $30 \mathrm{c}$.

7. Ковалів П. Значення І. Франка в розвитку літературної мови Галичини. Записки НTШ. T. CLXXXIV: Іван Франко. Збірник доповідей для відзначення 110-річчя народин і 50-річчя смерти Івана Франка. 1968. Ч. II. С. 5-12.

8. Коцовський В., Огоновський І. Методична граматика української мови. 4-те, попр. вид. Вінніпег : Накладом української книгарні, 1900. $102 \mathrm{c}$.

9. Лев В. Західно-українські признаки мови Івана Франка в його ранніх творах. Рідне слово. 1946. Ч. 6. С. 61-72.

10. Лев В. Участь І. Франка в творбі української літературної мови. Записки НТШ. Т. CLXVI. 1957. С. 125-132.

11. Лесюк М. Становлення і розвиток української літературної мови в Галичині : монографія. Івано-Франківськ : Місто НВ, 2014. 734 с.

12. Мозер М. Причинки до історії української мови. Харків : Харківське історико-філологічне товариство, 2008. XVI, 832 с.

13. Мозер М. Історія української мови. Київ, 2018. 30 с. URL: likbez.org.ua.

14. Муромцева О.Г. Язичіє. Украӥнська мова. Енциклопедія / ред. кол.: В.М. Русанівський, О.О. Тараненко (співголови). 2-ге вид., випр. і доп. Київ : «Українська енциклопедія» ім. М. Бажана. 2004. С. 812.

15. Нечуй-Левіцький I. Грамматика Украінського язика. Частка I. Етимологія. Київ : Друкарня Другої Артілі, 1913. 160 с.

16. Огієнко І. (Митрополит Іларіон). Історія української літературної мови. Либідь, 1995. 296 с.

17. Русанівський В. Історія української літературної мови. Київ : Артек, 2001. 392 с.

18. Смаль-Стоцький С., Гартнер Ф. Граматика руської мови. Вид. 3. Відень, 1914. 202 с.

19. Тимченко С. Українська граматика. 2-ге вид. Київ : Друкарня Ун-ту св. Володимира Акц. Т-ва друк. і видавн. діла, 1917. 168 с.

20. Ткач Л. Українська літературна мова на Буковині в кінці XIX на початку XX c. Частина 2: Джерела і соціокультурні чинники розвитку. Чернівці : Книги-XXI, 2007. 704 с.

21. Франко І. Говоримо на вовка - скажімо і за вовка. Франко I. Зібрання творів у 50-ти томах. Т. 28. Київ : Наукова думка, 1980. C. $167-175$.

22. Франко I. 3 вершин і низин. Переднє слово. Франко I. 3 вершин $i$ низин: Збірник поезій. 2-е, доповн. виданс. Львів, накладом Ольги Франко, 1893. С. 3-5. 
23. Франко І. Літературна мова і діялєкти. Літературно-науковий вістник. 1907. Т. XXXVII. Кн. 2. С. 225-230.

24. Франко I. Хто такий Лис і відки родом? Франко I. Лис Микита. Третє поправлене видання. Львів : Накладом Руського Товариства педагогічного, 1902. С. V-XV.

25. Франко I. Давнє й нове. Друге побільшене виданє збірки Мій «Ізмарагд». Львів: Накладом українсько-руської видавничої спілки, $1911.263 \mathrm{c}$.

26. Франко I. 3 вершин і низин: Збірник поезій. Друге, доповн. виданє. Львів, накладом Ольги Франко, 1893. 468 с.

27. Франко I. 3 вершин і низин : Збірник поезій. Львів : [Б.в.], 1887. $251 \mathrm{c}$.

28. Франко І. Зів'яле листє. Лірична драма. Львів: 3 друкарні Інст. Ставропігійського, 1896. 112 с.

29. Франко I. Мій ізмарагд: поезії. Львів: 3 друкарні нар. Ст. Манєцкого і Спілки під зарядом В. Годака, 1898. 174 с.

30. Ціхоцький І.Л. Мова прози Івана Франка (стилістичні новації). Львів : Вид.центр ЛНУ ім. І. Франка, 2006. 290 с.

31. Чапленко В. Історія нової української літературної мови. НьюЙорк, 1970. 446 c.

32. Шевельов Ю. Нарис сучасної української літературної мови та інші лінгвістичні студії (1947-1953 рр.) / упорядк.: Л. Белея, Л. Нуждак. Київ : Темпора, 2012. 664 с.

33. Шевельов Ю. Українська мова в першій половині двадцятого століття (1900-1941): Стан і статус. Чернівці : Рута, 1998. 208 с.

34. Шерех Ю. Мовна дискусія 1891-1893 років і участь у ній Івана Франка. Рідне слово. 1946. Ч. 6. С. 73-79.

\section{Information about the author:} Shmilyk I. D., Professor at the Ukrainian Language Department Lviv Polytechnic National University 2/4, Karpinskoho str., Lviv, 79013, Ukraine 